Conference Paper

\title{
Review of electrically powered propulsion for aircraft
}

Kulmanov, V., Anuchin, A., Ostrirov, V., Rusakov, A. and Vagapov, Y.

This is a paper presented at the 53rd IEEE Int. Universities Power Engineering Conference UPEC-2018, Glasgow, UK, 4-7 September 2018.

Copyright of the author(s). Reproduced here with their permission and the permission of the conference organisers.

\section{Recommended citation:}

Bolam, R., Vagapov, Y. and Anuchin, A. (2018), Review of electrically powered propulsion for aircraft. In: Proc. 53rd IEEE Int. Universities Power Engineering Conference UPEC-2018, Glasgow, UK, 4-7 September 2018, pp. 1-6. doi: 10.1109/UPEC.2018.8541945 


\section{Review of Electrically Powered Propulsion for Aircraft}

\author{
Robert Cameron Bolam, Yuriy Vagapov \\ School of Applied Science, Computing and Engineering, \\ Glyndwr University, Plas Coch, Mold Road, \\ Wrexham, LL11 2AW, UK
}

\begin{abstract}
This paper presents a review of the state-of-the-art in aircraft electrical propulsion technology. A comparison is provided of differing propulsion mechanisms such as propellers, open fans, ducted fans, multi-stage rim driven fans and distributed thrust designs and their suitability to particular flight profiles and mission applications. Electrical motor architectures are also reviewed with particular attention being given to synchronous machines, such as Brushless Direct Current (BLDC) and Switched Reluctance Motor (SRM) technologies, and the recent advances that have been made in solid-state switching and High Temperature Superconducting (HTS) material applications. Present day electrical power generation, storage and control technologies are also reviewed including hybrid and fuel cell technologies and regeneration techniques. Electrical storage capabilities with regard to specific power and energy characteristics are discussed and the extent to which existing system technology can be integrated onto a Hybrid-electric and an All Electric Aircraft (AEA) is also investigated. Finally, a conclusion is provided highlighting the current technological challenges facing the development of commercial aircraft in terms of performance, airframe configuration and legislative and operational infrastructural requirements.
\end{abstract}

Keywords-electrical propulsion, all electric aircraft, hybridelectric aircraft, more electric aircraft, unmanned aircraft, rim driven fan, high speed electrical flight, aircraft batteries, fuel cells, $P V$ cells, supercapacitors

\section{INTRODUCTION}

It may be claimed that energy management is one of the critical issues facing our society and that the importance of reducing harmful emissions into our atmosphere is now universally understood in the World. CO2 emissions have increased by about $80 \%$ between 1990 and 2014, and are forecast to grow by a further $45 \%$ between 2014 and 2035 . Also, NOx emissions have doubled between 1990 and 2014, and are forecast to grow by a further $43 \%$ between 2014 and 2035 [1].

Electrically propelled vehicles are increasingly popular in society with countries such as Norway, Hong Kong, and Iceland leading the way in adopting this environmentally friendly technology for their road and rail vehicles. However, electrical propulsion technologies for flight do not appear to be advancing as quickly. Although, successes like Solar Impulse's global circumnavigation and the recent boom in Small Unmanned Aircraft (SUA) technologies have highlighted the possibilities for electrically powered and autonomous flight. Technological hurdles such as power to weight ratios, the onboard storage of electrical charge and system control technologies seem to hamper "commercially feasible" development in the civil aviation sector.

Fortunately, national and international organisations such as the International Civil Aviation Organisation (ICAO), the National Aeronautics and Space Administration (NASA) and the Advisory Council for Aviation Research and Innovation in Europe (ACARE) have recognised their roles in guiding and encouraging environmentally responsible aviation and have begun to set goals, provide funding and conduct research

\author{
Alecksey Anuchin \\ Department of Electric Drives, \\ Moscow Power Engineering Institute, \\ 14 Krasnokazarmennaya Street, 111250, Moscow, Russia
}

aimed at improving the many aspects of aviation technology and operations necessary to protect our environment and energy resources [2]. The problem being addressed is how to reduce aircraft emissions and it is believed that electrical propulsion for aircraft can help to provide the solution. This report presents a review of the state-of-the-art in Electrically Powered Propulsion (EPP) for aircraft.

\section{COMPARISON OF ELECTRICAL PROPUlSION MECHANISMS}

The overall efficiency of an aircraft propulsion system $\eta_{o v}$ can be determined from the ratio of the effective propulsive power $P_{\text {Thrust }}$ to the power supplied by the energy source, $P_{\text {Sup- }}$ $p l y$ which may be aviation fuel or an electrical supply or a combination of these sources. An excellent comparison between electrically powered propulsion and gas turbine engines (GTEs) has been published by Seitz et al. [3]:

$$
\eta_{o v}=\frac{P_{\text {Thrust }}}{P_{\text {Supply }}}=\eta_{e c} \times \eta_{t r} \times \eta_{p r}
$$

where $\eta_{e c}$ is the energy conversion efficiency; $\eta_{t r}$ is the energy transmission efficiency; $\eta_{p r}$ is the propulsive efficiency.

Propulsive efficiency. Irrespective of whether the prime mover is an electrical motor or an Internal Combustion Engine (ICE) the propulsive efficiency is a fundamental parameter to be considered whenever matching a propeller or fan, to an aircraft. It represents the efficiency of the conversion of kinetic energy to propulsive work and may be expressed:

$$
\eta_{p r}=\frac{\text { Work done on the aircraft }}{\text { Energy imparted to the propulsive airflow }}
$$

This may be expressed in terms of aircraft velocity $\left(V_{a}\right)$ and the propelling airstream (jet) velocity $\left(V_{J}\right)$ to:

$$
\eta_{p r}=2 V_{a} /\left(1+\frac{V_{J}}{V_{a}}\right)
$$

The above equations illustrate that the lower the ratio of $V_{J}$ to $V_{a}$ the higher the propulsive efficiency. Therefore, at lower aircraft speeds propellers with slow moving airstreams are a suitable method of propulsion whereas at higher aircraft speeds fans or compressor with faster propelling airstreams become an efficient method [4], [5].
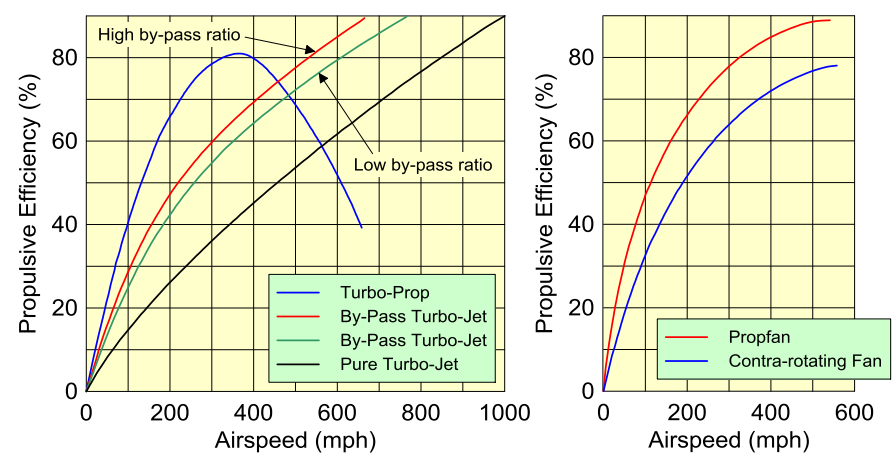

Fig. 1. Propulsive efficiency of gas turbine engine powered fans and propellers [5]. 
Fixed pitch propellers are the most common type of propeller used on electrical aircraft in order to simplify the propeller design and minimise its mass. However, they come with a performance penalty as the optimum pitch angle of a propeller depends on the aircraft's flight condition. For example, a low propeller pitch angle is best for take-off and a high angle is best for cruise. Hence the fixed pitch angle is normally a compromise to suit the purpose for which the aircraft is designed and consequently the propeller operates less efficiently during some of the aircraft's flight phases [6].

Variable pitch propellers allow for a more efficient operation during flight although at a cost in system weight, complexity and hence reduced reliability. The pitch can be continuously adjusted during flight to the optimum angle and this ensures that propulsive efficiencies are maintained around $80 \%$ up to $400 \mathrm{mph}(645 \mathrm{~km} / \mathrm{h})$, above this speed the airflow over the propeller tips becomes supersonic and causes a reduction in efficiency. Other advantages may be gained from the ability to feather the propellers, reverse their pitch or set them for electrical regeneration during the aircraft descent phase of flight [7]. Electrically actuated pitch control for propellers is common-place and has been in development since prior to 1944 [6].

Contra-rotating (counter-rotating) fan or propeller arrangements can provide a more efficient use of power and seem very well suited to electrically propelled aircraft owing to the simple direct power transmission designs that are achievable [6]. Regardless of whether the contra-rotating propellers are electrically or conventionally (ICE) driven, they avoid the spinning slipstream of the single propeller arrangement. Thus, for tractor aircraft configurations, they provide a symmetrical airflow over the wing and tail surfaces resulting in improved longitudinal and lateral stability. Other benefits are the cancellation of reaction-torque; the lessening of slipstream turbulence which enable aircraft designs with reduced wingspans; smaller ailerons; weight reductions in control surfaces and a reduction in aircraft drag [8].

Electrically powered propulsion (EPP) technology, in contrast to an ICE driven contra-rotating arrangement, allows each propeller to be directly driven by an independent motor arrangement and therefore has the potential to offer twin engine status, improved safety margins, reduced noise and vibration and improved "throttle response". Recently, Contraelectric Propulsion Ltd. has developed such a system with their $112.5 \mathrm{~kW}$ co-axial propeller shaft system suitable for light aircraft [9]. Studies of alternative EPP contra-rotating arrangements have also been carried out whereby the propeller

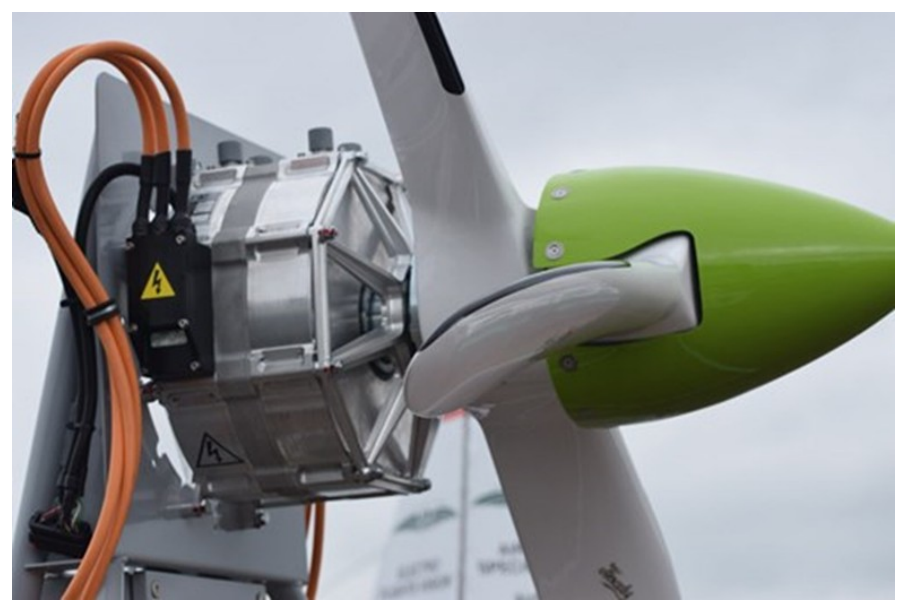

Fig. 2. High-density YASA electric motor for the Electroflight P1e [11].

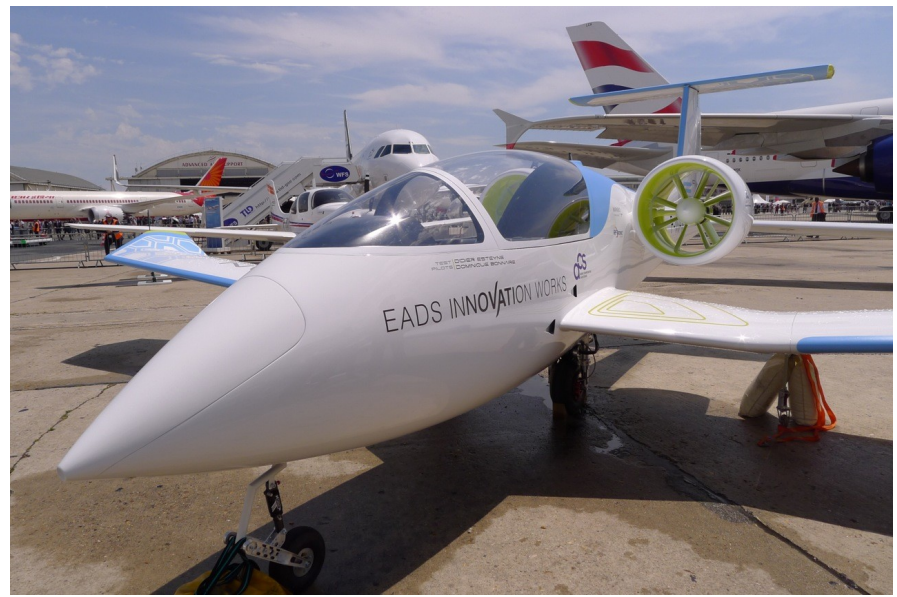

Fig. 3. Airbus E-fan [13].

blades are mounted directly to the rotor casing of a high-speed double rotor, axial-flux permanent magnet (PM) motor [10].

Ducted fans offer the potential for quieter and more efficient aircraft operation and allow higher airspeeds to be attained by the aircraft. The shrouding offered by the duct also serves to protect the fan blades and accelerate the exhaust airflow. Most applications of ducted fans on aircraft are conventional horizontal installations such as on the Airbus E-Fan in which $32 \mathrm{~kW}$ electric motors drive two ducted fans [12].

Electrically driven ducted fan aircraft designs have been studied for both manned and unmanned vertical take-off and landing (VTOL) aircraft applications [14], [15] and extensive computational fluid dynamic (CFD) modelling has been carried out to investigate the benefits of optimising the thrust generated and the aerodynamic manoeuvrability of these devices using phenomena such as the Coanda and Magnus effects [16].

Rim driven fans (RDF) are also a form of ducted electrical fan in which the fan blades are attached at their tips to a rotating rim or duct structure [18]. Investigative research has been conducted on these devices [19] with the perceived benefits being increased fan pressure ratios gained by multi-staged contra-rotating compressor configurations and also miniaturisation and airflow efficiency gains through hub-less RDF configurations. Rim driven fans offer the prospect of achieving high electrically powered aircraft speeds extending into the supersonic region of flight.

Open fan (or Prop fan). As thrust demands increase, for increasingly larger electrical aircraft projects, so too must the diameter of the fan. A suitable shrouding duct installation may then present excessive weight and structural problems. A solution may be to use an Open Fan (also known as a Prop-fan) engine design. Open fan engines can provide high propulsive efficiencies $(>80 \%)$ at speeds above $500 \mathrm{mph}(806 \mathrm{~km} / \mathrm{h})[5]$.

Distributed propulsion (Thrust) configurations. One of the main advantages offered by electric aircraft designs is their flexibility regarding their power-plant installation. The distributed propulsion (DP) concept for aircraft has been in development since the early 1920s [20] however it is only recently, since all electric and hybrid-electric aircraft propulsion has been considered, that DP has become a feasible concern. Research conducted on DP has highlighted many potential benefits including achieving high engine by-pass ratios without requiring huge fan diameters, boundary layer ingestion and reduced noise "Silent Aircraft" [21]. Distributed thrust studies have been considered for conventional "tube and wing" and also blended-wing-body (BWB) aircraft designs. 


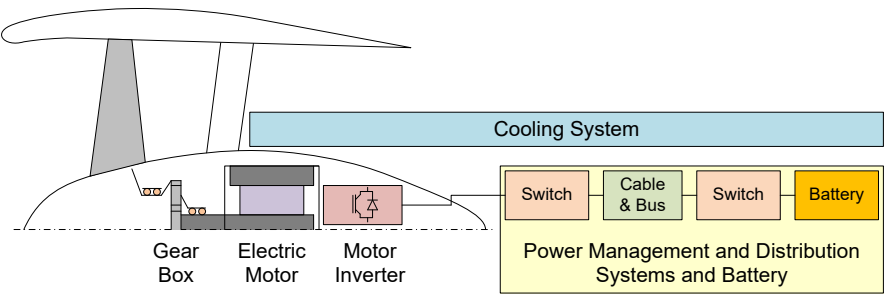

Fig. 4. Typical electrically powered ducted fan system [17].

\section{ElECTRICAL MOTOR AND CONTROL TECHNOLOGY}

Although the operation of electrical motors is based on common electromagnetic principles they can differ widely in their actuation and control. The four main types of motors used in electrical vehicle (EV) propulsion are Induction Motors, Brushed DC Motors, Brushless DC Motors (BLDC) and Switched Reluctance Motors (SRM). Of these four types, the BLDC and switched reluctance motors are currently considered the most suitable for aircraft propulsion applications due to their high specific power and reliability when compared with induction or brushed DC motor types [22]. Both SRM and BLDC motors are simple, robust and compact synchronous machines that do not require a supply of electrical current to their rotors. However, in order to operate they do require complicated control circuitry which is based on programmed microprocessor and solid-state (electronic) switching technology.

Studies aimed at increasing the power density and efficiency of electrical motors, intended for all electric flight, have also considered axial flux motor designs rather than the more conventional radial flux machines [23] combined with the use of high temperature superconducting (HTS) materials and trapped flux magnets. From which theoretical results are indicating motor efficiencies in excess of $99 \%$ [24].

\section{Electrical Power Generation AND StORAGE}

Battery technology. Battery powered aircraft can provide very high total efficiency chains, in excess of $70 \%$, when compared with current ICE chain efficiencies of less than $40 \%$ for turbofans and turbo-props [25]. They also have the advantage of zero emissions, low maintenance and no centre of gravity (CG) movement during flight. Currently the main disadvantages of using battery system technology are: the reduced flying range of the aircraft; the relatively high aircraft weight (which does not change between take-off and landing) and the issues relating to the recycling of batteries.

Specific Power is a key performance parameter that relates to the amount of power obtainable per kilogram of a genera-

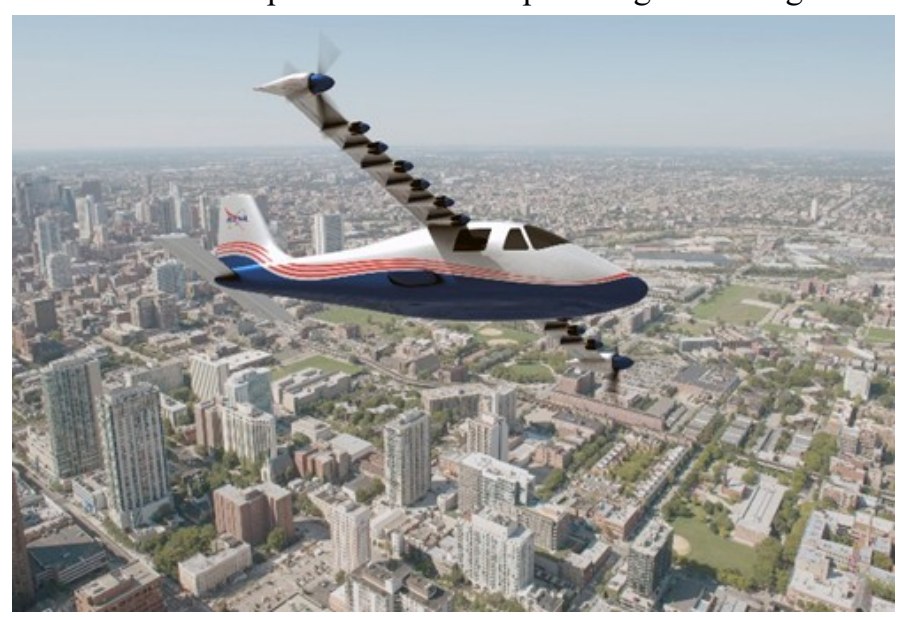

Fig. 5. NASA's X-57 distributed thrust Electric Research Plane [21].

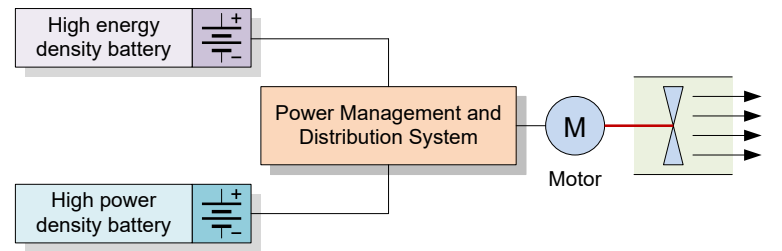

Fig. 6. Battery System Design for high specific power and energy [26].

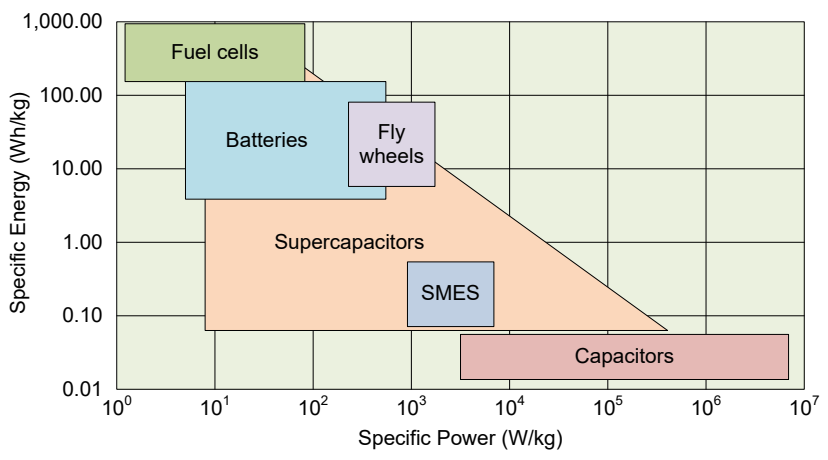

Fig. 7. Ragone chart [28].

tion or storage device $(\mathrm{W} / \mathrm{kg})$, whilst Energy Density is the amount of electrical energy stored per cubic meter of the device $\left(\mathrm{Wh} / \mathrm{m}^{3}\right)$ and Specific Energy is the amount of energy stored per kilogram of the device's mass (Wh/kg) [22]. Batteries may have a high value of specific energy but generally have low values of specific power. For example, a battery may be capable of storing much energy but is only able to release it slowly and therefore, such a battery may be useful in an electrical aircraft to provide range but not acceleration. In their paper [27] on Electric Air Transport, Kuhn et al., present a parallel battery system intended to optimise battery performance utilising two different types of batteries: one having a high specific power $(\mathrm{P})$ and the other a high specific energy (E) (Fig. 6). This ratio of specific energy to specific power of a battery is a very important technology performance comparator which is often graphically represented using a Ragone plot, see Fig. 7.

Battery technologies in aircraft usage are: lead Acid batteries in General Aviation (GA) and Light Aircraft; Nickel Cadmium batteries on larger aircraft and helicopters and Lithium Ion batteries on large More Electric Aircraft (MEA) such as the Boeing 787 Dreamliner [20] and all electric aircraft such as the Airbus E-Fan which has a Lithium-ion ICR 18650 [30] with a specific energy per battery cell of $207 \mathrm{Wh} / \mathrm{kg}$ and a total available energy of $29 \mathrm{kWh}$ for a battery weight of $167 \mathrm{~kg}$, providing an endurance of 1 hour with 30 minutes reserve [12].

Interest in metal-air battery technology is on the increase because of its extremely high energy density compared to that of other battery technologies (Fig. 8) [31]. This technology differs from Lithium-ion battery technology as metal-air batteries cannot be recharged by reversing the current direction, because the metal electrodes are irreversibly altered as part of the reaction process, thus requiring replacement and reprocessing once spent. From an aircraft operators' viewpoint metal -air batteries may therefore be considered as requiring "refuelling" [22]. A special feature of these batteries compared to conventional batteries is the air-breathing electrode required to supply the cathode active material (oxygen). Metal -air batteries can be based on a variety of metal electrode materials such as $\mathrm{Li}, \mathrm{Zn}, \mathrm{Al}, \mathrm{Na}, \mathrm{Mg}, \mathrm{Ca}$ or $\mathrm{Fe}$ and require a metal-ion conducting electrolyte. The electricity is generated through the reduction and oxidation processes between the metal and the oxygen [32]. 


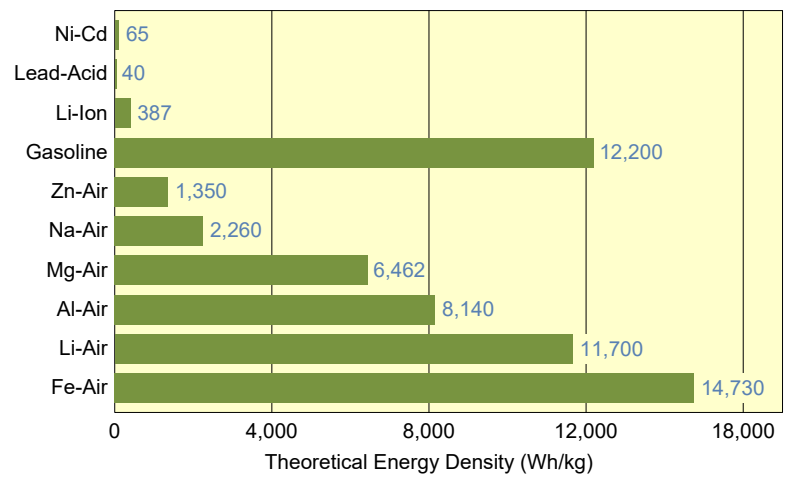

Fig. 8. Theoretical specific energies of batteries compared to gasoline [31].

Super-capacitors (Ultra-capacitors) which are otherwise known as ultra-capacitors can produce much higher specific powers (multiple $\mathrm{kW} / \mathrm{kg}$ ) but have lower specific energy capacities (currently only a few $\mathrm{Wh} / \mathrm{kg}$ ) than batteries. Battery system design performs a trade-off between specific energy and specific power and supercapacitors can offer a way of satisfying peak power demands over relatively short durations. Battery/Supercapacitor power sharing in this way is a fundamental principle of a hybrid energy storage system (HESS) [33] and a major factor in sizing the battery system and determining its cycle life [34]. Examples of such peak power demands are those present during take-off and climb.

The most common types of supercapacitors are electrical double layer capacitors (EDLCs) which store electrical energy in an electrostatic field e.g. similar to the static build up on a balloon. They are very durable, capable of achieving millions of cycles and have relatively fast charging and discharging rates when compared with battery technology. Examples of EDLC applications can be found in the economising stop-start systems of modern road vehicles [35]. There are also environmental benefits of using these types of supercapacitors as they do not require expensive materials such as Lithium and Cobalt in their manufacture [36] and can therefore avoid the associated flammability and toxicity issues.

Supercapacitors provide a credible alternative to Lithium Ion battery technology and national and industrial organisations are showing an increased interest in the development of this technology. Although there are new types of Hybridsupercapacitors currently in development based on established Lithium-ion technology [35]. NASA Kennedy Space Center is investigating the development of graphene-based ultracapacitors, which utilise the large accessible surface area of graphene $\left(2,600 \mathrm{~m}^{2} / \mathrm{g}\right)$, to increase the electrical energy that can be stored [37],[38] and recent media reports suggest that aqueous supercapacitor development work, carried out by Superdielectrics Ltd., will soon enable specific energy capacities of up to $180 \mathrm{Wh} / \mathrm{kg}$ to be achieved [36].

Fuel cells (FCs) are similar to batteries in that they produce electricity based on a chemical reaction. The most common types of chemicals used are Hydrogen and Oxygen although some fuel cells use methane or methanol [22]. The main difference between a fuel cell operation and that of an ICE is that energy is released as an electric current rather than heat therefore, compared with ICE vehicles, fuel cells offer high energy efficiency and low emissions [34]. Fuel cells have demonstrated higher specific energies than Lithium Ion battery technology of up to $1980 \mathrm{~kJ} / \mathrm{kg}(550 \mathrm{Wh} / \mathrm{kg})$ although their rate of energy release (specific power) is lower. For this reason, FC installations on aircraft require a hybrid system approach to meet peak power requirements such as during take-off and climb [39]. Fuel Cells also require the pressurised on-board storage of hydrogen and a supply of air during flight.

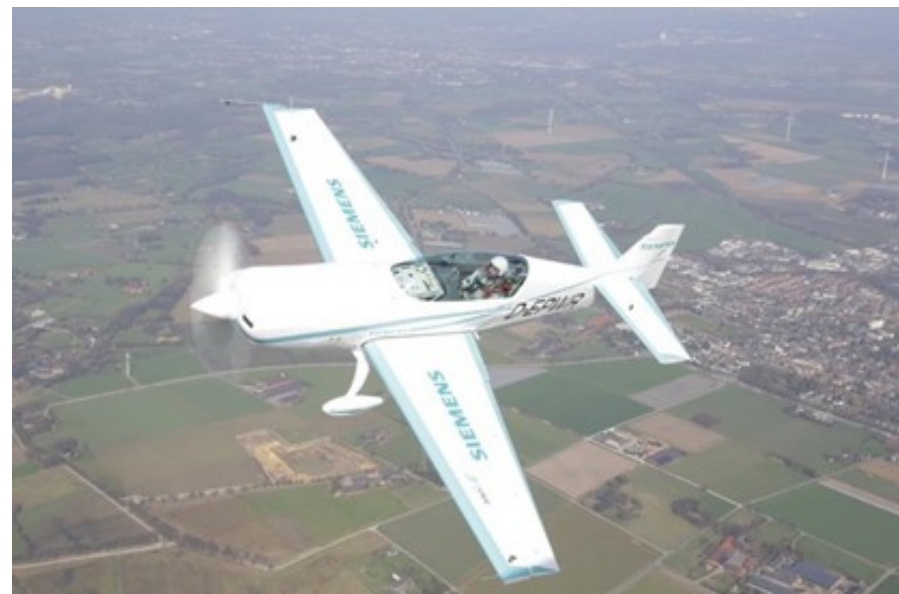

Fig. 9. The Extra 330LE aerobatic plane, powered by a lightweight hybridelectric propulsion system, set a new record when it reached $337.5 \mathrm{~km} / \mathrm{h} \mathrm{[40]}$.

These are restricting factors when considering the system's installation on an aircraft.

Hybrid-electric aircraft systems have two or more power sources the most common being a combination of electrical power with an ICE. These systems are divided into two main categories, namely series hybrid and parallel hybrid, and are determined by the arrangements of their electrical and mechanical drive components. In a series hybrid arrangement the aircraft propulsion mechanism e.g. the propeller, is purely driven from an electrical supply e.g. via a motor, and in this case the ICE simply powers a generator which supplies current to the system. Whereas in a parallel hybrid arrangement the propulsion mechanism may also be driven mechanically by the ICE via a shaft and gears etc. (Fig. 10) [41].

A term commonly applied to describe parallel hybridelectric aircraft systems is the degree of hybridisation $(\mathrm{DOH})$ :

$$
\mathrm{DOH}=\frac{\text { electric motor power }}{\text { electric motor power }+ \text { IC engine power }}
$$

The greater the degree of hybridisation indicates the more scope there is to use electrical propulsion techniques and minimise the ICE input power [22] although Pornet and Isikveren [42] postulate that advanced aircraft hybrid-electric systems cannot be suitably represented by such a single DOH parametric descriptor.

Hybrid-electrical aircraft are considered the logical step towards achieving all electric aircraft capabilities. In June 2011, Diamond Aircraft, Siemens, Austro Engine and Airbus (then known as EADS) presented the Diamond DA36 E-Star as the world's first serial hybrid aircraft at Paris Airshow [42].

Flywheels offer a means of mechanically storing energy and generally have high specific power ratings thus they can

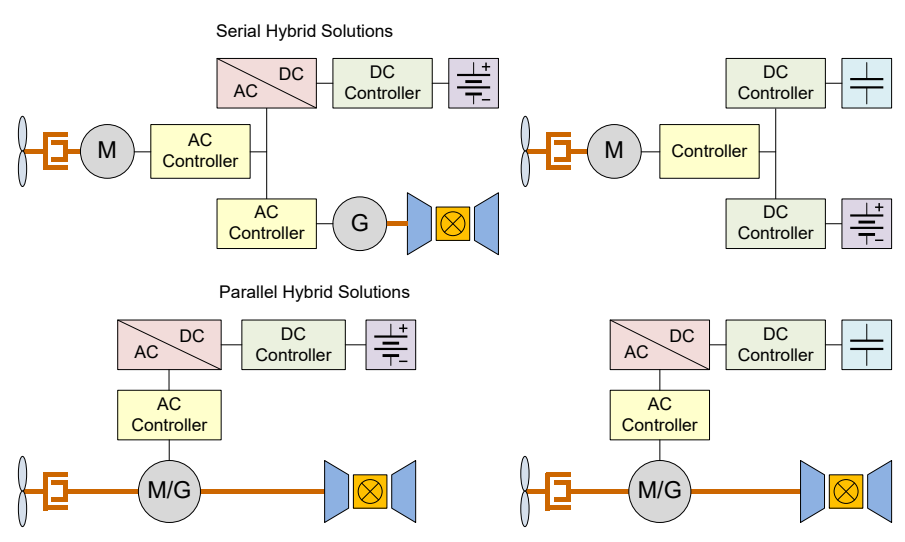

Fig. 10. Series and parallel hybrid arrangements [41]. 
store and release energy relatively quickly [22]. There are examples of flywheel applications on terrestrial electrical vehicles notably the "Gyrobus" developed by the Oerlikon Engineering Company [32] although few examples can be found for aircraft applications which is probably owing to the perceived weight and installation concerns. Consideration continues to be given to the likely benefits offered by flywheels; such as the release of stored energy during take-off to reduce the engine workload or shorten runways and the ability to assist motors to spool up more quickly when power is re-applied after idling [43]. Recent developments in this technology have produced ultra-high-speed flywheels of only tens of kilograms mass running, in evacuated housings on magnetically levitated bearings, at speeds in excess of 100,000 rpm [44].

Energy recovery systems offer the potential to optimise aircraft energy consumption whilst operating both in flight and on the ground. Studies conducted on High altitude long endurance (HALE) Unmanned Air Vehicles (UAVs) have considered the benefits of incorporating Regenerative Fuel Cell (RFC) technology using photovoltaic arrays during the day to regenerate hydrogen and oxygen [45]. Studies have also been conducted to test the efficiency of electrical regenerators connected to aircraft electro-mechanical actuators [46] and in 2007 Delos Aerospace patented a fully electric landing gear system which recovered kinetic energy during aircraft braking (KERS) that could later be utilised during taxying and take-off by driving the wheels of the aircraft and helping to shorten runway requirements and assist noise abatement [47].

Photovoltaic (PV) technology. Modern photovoltaic technology started its development with the silicon PV cell in the USA as far back as 1954 and by 1964 NASA had placed the Nimbus satellite in space powered with a $470 \mathrm{~W}$ solar array. A decade later the first solar powered aircraft (Sunrise 1) was launched with a MTOM of $12 \mathrm{~kg}$ it had 4096 PV cells of $11 \%$ efficiency and produced $450 \mathrm{~W}$ of power [48]. An important performance parameter for PV cells is its solar conversion efficiency which is normally expressed as a percentage of the electrical energy produced to the solar energy to which it is exposed.

Nowadays there are numerous PV technologies available such as silicon based, organic cells, polymer cells, hybrid PV cells and thin-film solar cells and the efficiencies being achieved are as high as 44\% [49]. However silicon based PV cells are currently considered the only suitable solution for solar powered aircraft on design and cost effectiveness reasons. These can be made from mono-crystalline, multicrystalline or amorphous silicon and provide efficiencies around $16-22 \%$. Recently SunPower provided the 22,000 PV cells incorporated in the wings and tailplane of the Solar Impulse aircraft. Each PV cell being only 135 microns thick and producing an efficiency of approximately $22.7 \%$ [50].

\section{CONCLUSION}

Aircraft emission reduction targets set at national and international levels have helped to ensure that research and development into electrically powered propulsion for aircraft has become a rapidly growing area of technology. With numerous major and minor aerospace companies now conducting electrical propulsion programmes for future light aviation and large commercial aircraft applications.

Power generation and storage present the greatest hurdles facing electrically powered propulsion with the most feasible aircraft designs to date being based on hybrid-electric archi- tectures such as the Zunum Aero's regional hybrid-electric plane [52] and the E-Fan X hybrid-electric flight demonstrator project currently being conducted by Airbus, Rolls-Royce and Siemens [53].

An important factor in achieving electrically powered propulsion is the weight and aerodynamic efficiency of the airframe design. Approximately $50 \%$ of the Airbus A350 and Boeing 787 Dreamliner airframes are currently comprised of lightweight composite materials. However, future electrical aircraft projects are already considering a move away from conventional wing and tube aircraft towards BWB designs with distributed thrust and higher composite material contents. Novel electrical motor configurations are also likely to have an impact on electrical aircraft performance capabilities. Rim driven and multi-staged fans that are based on axial flux motor arrangements, could facilitate high aircraft speeds. Iron-less rotors can reduce rotational stresses and increase motor reliability and Halbach arrays of permanent magnets could improve magnetic field concentrations [54].

The limitations of state-of-the-art battery technology, particularly associated with low values of specific power, are restricting the performance of all electric aircraft designs to low speed and short endurance flight envelopes. However recent advances in materials technology, especially relating to graphene and HTS materials and their implications for battery, supercapacitor, SMES and motor technologies have offered grounds for optimism and the possibility that, in the not too distant future, electrically powered aircraft performance will be able to match or surpass that of ICE technology.

It is also important that the requirements for ground-based support are considered and keep equal pace with this rapidly advancing aerospace technology. For example regional and hub airports will require the necessary infrastructure to supply electrical power to meet aircraft demands and maintenance bases will require the necessary training and equipment to service electrical aircraft. Novel airport features such as the ground supply of electrical power to assist an aircraft's takeoff run could be considered and the airworthiness regulations and new requirements applicable to the manufacture, operation and maintenance of electrical aircraft will need to be developed.

\section{REFERENCES}

[1] European Aviation Safety Agency, European Aviation Environmental Report 2016. Luxembourg: Publications Office, 2016.

[2] European Commission, Flightpath 2050 Europe's Vision for Aviation: Report of the High Level Group on Aviation Research. Luxembourg: Publications Office, 2011.

[3] A. Seitz, O. Schmitz, A.T. Isikveren, and M. Hornung, "Electrically powered propulsion: Comparison and contrast to gas turbines," in Proc. Conf. Deutscher Luft- und Raumfahrtkongress, Berlin, Germany, 10-12 Sept. 2012, paper 281358, pp. 1-14.

[4] S. Hooker, Not Much of an Engineer: Sir Stanley Hooker an Autobiography. Shrewsbury: Airlife Publishing, 1984.

[5] Rolls Royce, The Jet Engine, 5th ed. Chichester: Wiley, 2015.

[6] Propeller Theory. Caldwell, NJ: Curtiss-Wright Co., 1944.

[7] J. Thauvin, G. Barraud, X. Roboam, B. Sareni, M. Budinger, and D. Leray, "Hybrid propulsion for regional aircraft: A comparative analysis based on energy efficiency," in Proc. Int. Conf. on Electrical Systems for Aircraft, Railway, Ship Propulsion and Road Vehicles and Int. Transportation Electrification Conf. (ESARS-ITEC), Toulouse, France, 2 -4 Nov. 2016, pp. 1-6.

[8] Electroflight (2018). Aerospace vision. Electric propulsion. [Online]. Available: https://www.electro-flight.com/aerospace-vision 
[9] Contraelectric (2018). Electric propulsion. Undeniably the future of aviation. [Online]. Available: https://www.contraelectric.com/ innovation/the-system-components

[10] G. Brando, A. Dannier, A. Del Pizzo, and L.P. Di Noia, "A direct drive solution for contra-rotating propellers in electric unmanned aerial vehicle," in Proc. Int. Conf. on Electrical Systems for Aircraft, Railway, Ship Propulsion and Road Vehicles, Aachen, Germany, 3-5 March 2015, pp. $1-6$.

[11] T. Robinson (March 3, 2017). Bright sparks - The quest for electric speed. [Online]. Available: https://www.aerosociety.com/news/brightsparks-the-quest-for-electric-speed

[12] Airbus Group, E-Fan. The New Way to Fly. Corp. Tech. Office, 2015.

[13] J. Paur (June 18, 2013) Being electric doesn't keep this plane from serious aerobatics, Wired. [Online]. Available: https:// www.wired.com/2013/06/e-fan-electric-airplane

[14] X. Wang, G. Sin, and K. W. Eric Cheng, "Future body design for electric vessel and aircraft," in Proc. 6th Int. Conf. on Power Electronics Systems and Applications, Hong Kong, 15-17 Dec. 2015, pp. 1-5.

[15] W. Shuai, and Q. Xiao-hui, "Aerodynamic data model analysis and simulation of ducted fan UAV," in Proc. Int. Conf. on Electronics, Communications and Control, Ningbo, China, 9-11 Sept. 2011, pp. 699-702.

[16] J. Zhao, Q. Hou, H. Jin, J. Yan, Y. Zhu, and G. Li, “Aerodynamic characteristics analysis and robustness analysis of ducted fan UAV based on Magnus effect," in Proc. IEEE Int. Conf. on Information and Automation, Yinchuan, China, 26-28 Aug. 2013, pp. 892-897.

[17] P.C. Vratny, and M. Hornung, "Sizing considerations of an electric ducted fan for hybrid energy," Transportation Research Procedia, vol. 29, pp. 410-426, 2018.

[18] D.J. Eichenberg, C.A. Gallo, P.A. Solano, W.K. Thompson, and D.R Vrnak, "Development of a 32 inch diameter levitated ducted fan conceptual design," NASA Glenn Research Centre, Cleveland, Ohio, Rep. NASA/TM-2006-214481, Dec. 2006.

[19] R.C. Bolam, and Y. Vagapov, "Implementation of electrical rim driven fan technology to small unmanned aircraft," in Proc. Int. Conf. on Internet Tech. and App., Wrexham, UK, 12-15 Sept. 2017, pp. 35-40.

[20] A.S. Gohardani, G. Doulgeris, and R. Singh, "Challenges of future aircraft propulsion: A review of distributed propulsion technology and its potential application for the all electric commercial aircraft," Progress in Aerospace Sciences, vol. 47, no. 5, pp. 369-391, July 2011.

[21] R. Kirner, L. Raffaelli, A. Rolt, P. Laskaridis, G. Doulgeris, and R. Singh, "An assessment of distributed propulsion; Advanced propulsion system architectures for conventional aircraft configurations," Aerospace Science and Technology, vol. 46, pp. 42-50, Oct.-Nov. 2015.

[22] J. Larminie, and J. Lowry, Electric Vehicle Technology Explained. Chichester: Wiley, 2012.

[23] A. Cavagnino, M. Lazzari, F. Profumo, and A. Tenconi, "A comparison between the axial flux and the radial flux structures for PM synchronous motors," IEEE Trans. on Industry Applications, vol 38, no. 6, pp. 1517 1524, Nov/Dec 2002.

[24] P.J. Masson, M. Breschi, P. Tixador, and C.A. Luongo, "Design of HTS axial flux motor for aircraft propulsion," IEEE Trans. on Applied Superconductivity, vol. 17, no. 2, pp. 1533-1536, June 2007.

[25] M. Hepperle, "Electric flight - Potential and limitations," in Proc. Workshop on Energy Efficient Technologies and Concepts of Operation, Lisbon, Portugal, 22-24 Oct. 2012, pp. 1-30.

[26] H. Kuhn, A. Seitz, L. Lorenz, A. T. Isikveren, and A. Sizmann; "Progress and perspectives of electric air transport," in Proc. 28th Int. Congress of Aeronautical Sciences, Brisbane, Australia, 23-28 Sept. 2012, pp. 1-14.

[27] H. Kuhn, A. Seitz, L. Lorenz, A. T. Isikveren, and A. Sizmann; "Progress and perspectives of electric air transport," in Proc. 28th Int. Congress of Aeronautical Sciences, Brisbane, Australia, 23-28 Sept. 2012, pp. 1-14.

[28] A. Rufer, "The dream of efficient energy storage - From BESS, KERS \& Co to the hybrid power plant," in Proc. 19th European Conf. on Power Electronics and Applications (EPE'17 ECCE Europe), Warsaw, Poland, 11-14 Sept. 2017, pp. P.1-P.9.

[29] Boeing Aircraft Corporation (2013). 787 Lithium-ion battery events: A guide for firefighters. [Online]. Available: http://www.boeing.com/ assets/pdf/commercial/airports/faqs/787batteryprocedures.pdf

[30] Samsung (May, 2009). ICR18650-26F LIB battery specification. [Online]. Available: https://www.batteryspace.com/prod-specs/ ICR18650-26F.pdf
[31] T. Yu, J. Fu, R. Cai, A. Yu, and Z. Chen, "Nonprecious electrocatalysts for Li-air and $\mathrm{Zn}$-air batteries: Fundamentals and recent advances," IEEE Nanotechnology Magazine, vol. 11, no. 3, pp. 29-55, Sept. 2017.

[32] M.E. Amiryar, and K.R. Pullen, "A review of flywheel energy storage system technologies and their applications," Applied Science, vol. 7, no.3, 2017, article 286, pp. 1-21.

[33] R. Abdelhedi, A. Lahyani, A.C. Ammari, A. Sari, and P. Venet, "Reinforcement learning-based power sharing between batteries and supercapacitors in electric vehicles," in Proc. IEEE Int. Conf. on Industrial Technology, Lyon, France, 20-22 Feb 2018, pp. 2072-2077.

[34] M. Ehsani, Y. Gao, S. Longo, and K. Ebrahimi, Modern Electric, Hybrid Electric and Fuel Cell Vehicles, 3rd ed. Boca Raton, FL: CRC Press, 2018.

[35] J. Libich, J. Maca, J. Vondrak, O. Cech, and M. Sedlarikova, "Supercapacitors: Properties and applications," Journal of Energy Storage, vol. 17, pp. 224-227, June 2018.

[36] A. Katwala (March 1, 2018) A fluke breakthrough could be the missing link for an electric car age, Wired. [Online]. Available: http:// www.wired.co.uk/article/superdielectrics-supercapacitor-electric-carbattery

[37] C.I. Calle, "Graphene-based filters and supercapacitors for space and aeronautical applications," in Proc. 24th Int. Materials Research Congress, Cancun, Mexico, 16-20 Aug. 2015, pp. 1-39.

[38] M. Meyyappan, "Metal oxide vertical graphene hybrid supercapacitors," U.S. Patent 9911 544, Mar 6, 2018.

[39] J. Sliwinski, A. Gardi, M. Marino, and R. Sabatini, "Hybrid-electric propulsion integration in unmanned aircraft," Energy, vol. 140, part 2, pp. 1407-1416, Dec. 2017.

[40] K. Deamer (April 11, 2017). $210 \mathrm{mph}$ ! Electric plane beats speed record. [Online]. Available: https://www.livescience.com/58624-electricpowered-plane-sets-speed-record.html

[41] C. Pornet, and A.T. Isikveren, "Conceptual design of hybrid-electric transport aircraft," Progress in Aerospace Sciences, vol. 79, pp. 114135, Nov. 2015.

[42] Diamond Aircraft (2018). Propulsion innovation. [Online]. Available: https://www.diamondaircraft.com/about-diamond/innovation/

[43] Flywheel Technology (KERS) In Aviation? [Online]. Available: http:// www.airliners.net/forum/viewtopic.php?t=770159

[44] W. Wang, H. Hofmann, and C.E. Bakis, "Ultrahigh speed permanent magnet motor/generator for aerospace flywheel energy storage applications," in Proc. IEEE Int. Conf. on Electric Machines and Drives, San Antonio, TX, USA, 15 May 2005, pp. 1494-1500.

[45] M.-Y. Cha, M. Kim, Y.-J. Sohn, T.-H. Yang, and S.-G. Kim, "Flight paths for a regenerative fuel cell based high altitude long endurance unmanned aerial vehicle," Journal of Mechanical Science and Technology, vol. 30, no. 7, pp. 3401-3409, July 2016.

[46] F. Ciancetta, N. Rotondale, A. del Pizzo, and M. Nardi, "Development of a measurement system to test the efficiency of electrical generators for energy recovery on aircraft actuators," in Proc. Int. Conf. on Clean Electrical Power, Alghero, Italy, 11-13 June 2013, pp. 564-570.

[47] D. Sigler (March 22, 2012). A not totally new idea after all. [Online]. Available: http://cafe.foundation/blog/a-not-totally-new-idea-after-all

[48] X.-Z. Gao, Z.-X. Hou, Z. Guo, X.-Q. Chen, "Reviews of methods to extract and store energy for solar-powered aircraft," Renewable and Sustainable Energy Reviews, vol. 44, pp. 96-108, April 2015.

[49] NREL. Research cell record efficiency chart. [Online]. Available: https://www.nrel.gov/pv/assets/images/efficiency-chart.png

[50] The Solar Company (2018). Remember the remarkable solar plane that surpassed a 24-hour test flight? [Online]. Available: https:// www.thesolarco.com/sunpower-supplies-solar-cells-for-the-solarimpulse/

[51] T. Tschida (2000). Technician Marshall MacCready installs solar cells on the Helios prototype. [Online]. Available: https://www.dfrc.nasa.gov/ Gallery/Photo/Helios/Small/EC00-0283-4.jpg

[52] M. Knapp, and W. Said, "Electric blue skies," IEEE Spectrum, vol. 55, no. 5, pp. 26-52, May 2018.

[53] T. Robinson (Dec. 1, 2017). How E-Fan X will jump-start a new era in hybrid-electric flight. [Online]. Available: https://www.aerosociety.com/ news/how-e-fan-x-will-jump-start-a-new-era-in-hybrid-electric-flight

[54] P.K. Duffy, "Optimizing power density and efficiency of a doubleHalbach array permanent-magnet ironless axial-flux motor," in Proc. 52nd AIAA/SAE/ASEE Joint Propulsion Conf., Salt Lake City, UT, USA, 25-27 Jul. 2016, pp. 1-12. 